\title{
A Study on Introspection and Reconstruction of the Goals of Entrepreneurship Education in Private Colleges and Universities
}

\author{
Li Chen \\ Innovation and Entrepreneurship School of Xi’an Fanyi University, Xi’an, Shaanxi, China, 710105
}

Keywords: private colleges and universities; the goal of entrepreneurship education; introspection and reconstruction

\begin{abstract}
The paper analyzes the development, advantages, disadvantages and the problem to be solved in entrepreneurship education of private colleges and universities, and points out that the entrepreneurship education in colleges and universities aims not only to train talents that can start a business, but also to cultivate more talents with pioneering awareness etc. Meanwhile, this paper gives some suggestions that the training objectives for entrepreneurship education in private colleges and universities must combine theory with practice and be multi-specialized, individualized and diversified, and an entrepreneurial education system should be built for application-oriented compound talents to meet market demand.
\end{abstract}

\section{Introduction}

The entrepreneurship education could not work well in stimulating employment and promoting the success of entrepreneurship. Therefore, it is necessary to Introspect on the current entrepreneurship education. Due to a record-breaking 6.99 million graduates, 2013 was jokingly referred to as "the hardest job season in history". The number of graduates in 2014, 2015, and 2016 has gradually increased ear by year, and In 2017, graduates surprisingly to 7.65 million. University graduates have to face a terrible employment situation, meanwhile, private graduates are under the greater employment pressure so that the employment rate directly influences the enrollment of schools and the normal operation of schools. "The development strategy for expanding and promoting employment through entrepreneurship" is an urgent need to solve employment problems for university graduates, and to promote the sustained, healthy, and rapid development of China's economy. In recent years, a series of policies introduced by Chinese government encourage university students to start their own businesses. In May 2015, "Implementation Opinions of the General Office of the State Council on Deepening the Reform of Innovation and Entrepreneurship Education in Colleges and Universities issued by the State" vigorously deepened innovation and entrepreneurship reform and promoted higher-quality entrepreneurial employment for college graduates. Now, entrepreneurship has become an important way for university graduates to improve their employment quality. However, it is reported that the success rate of entrepreneurship for university students in China in 2011 is about 1\%, [1] but in the world around 10\%, and in the United States 20\%. The entrepreneurial ability of Chinese college students is far from the world average. [2]

\section{The Development of Entrepreneurship Education in Private Colleges and Universities}

\subsection{The advantages of entrepreneurship education in private colleges and universities}

There are many inherent advantages in entrepreneurship education of private universities over public universities. China's entrepreneurship education has gradually been promoted in colleges and universities across the country after being piloted by universities such as Tsinghua University and Beijing Aerospace University. That entrepreneurship education in private universities is generally less developed than that of public universities resulted in a big gap in understanding entrepreneurship education, target orientation, curriculum setting, and the strength of teachers, etc. 
Firstly, there are more flexible school-running mechanisms and school-running advantages for privately-run universities: such as, less subject to policy constraints than public institutions, professional settings relatively close to market demands, closer school-enterprise cooperation, better understanding characteristics of innovation and entrepreneurship education in practice, awareness of the needs of different groups of innovation and entrepreneurship education and learning styles, and relatively flexible internal management, etc, so privately-run universities can provide teachers and students with more policy support and greater opportunities. Secondly, privately-funded college students have more entrepreneurial passions than public universities students. It is well-known that here is a big gap between the students of privately-run universities and the students of public ones. When many enterprises recruit new graduates, they will recruit students graduated from 985 or 211 universities and many employers have made it clear that they will not employ private graduates. So graduates of private universities have no competitive advantages in terms of employment. The severe employment situation forces some graduates to seek employment through business startups.

\subsection{The disadvantages of entrepreneurship education in private colleges and universities}

In private universities, there are some innate deficiencies in carrying out entrepreneurship education that was influenced by external factors such as national policies, the severe employment situation and their own policies. First, entrepreneurship education in private universities started much later than that in state-run ones, and insufficient attention is paid to entrepreneurship education, meanwhile, some people clung to old view of entrepreneurship education. Since the start of entrepreneurship education is not long, the research on entrepreneurship education needs to be gradually deepened. Many private universities started their entrepreneurship education in recent years so that they have not paid sufficient attention to issues of entrepreneurship education so far. Second, entrepreneurship education is in a low position in the process of personnel training. Although entrepreneurship education as a compulsory or elective course has been set up in some privately-run universities, it is taught in a large class and main theories are taught to the students. For students choose the course in order to take credits, the effect of learning can't meet the need of the universities.

\section{Opinions about Entrepreneurship Education}

The definition of entrepreneurship education is controversial among the academic community.

UNESCO defines it as follows, "Entrepreneurship education aims to cultivate individuals with pioneering spirits and it is of the same importance for those who receive salaries, because employers not only require employees to make achievements in their careers but place the more emphasis on the pioneering, adventurous spirit, entrepreneurial capabilities and independence, as well as technology, diplomacy and managerial skills.”

Scholar Mingyuan Gu thinks that so-called entrepreneurship education means students should not passively wait for employers to recruit and employ, but bravely start their own business before employment opportunities come. ${ }^{[3]}$

The definition of UNESCO clearly states that the purpose of entrepreneurship education is not only to train students to start a business, but to cultivate entrepreneurs with entrepreneurial awareness, spirit and skills. Scholar Mingyuan Gu emphasizes that in entrepreneurship education students should change their passive concept of employment, and accept active entrepreneurship to master entrepreneurial knowledge and skills, and improve their employment, adjustment and entrepreneurship. Meanwhile, students should have the courage to start their own businesses, learn to develop oneself.

What kind of entrepreneurs does entrepreneurship education cultivate? There are four kinds of entrepreneurs: corporate entrepreneurs, social entrepreneurs, internal entrepreneurs and policy entrepreneurs. Corporate entrepreneurs refer not only to the entrepreneurs who found and own a company to pursue profits, but generally to those who organize, operate, and dare to take on 
commercial or corporate risks. Corporate entrepreneurs do not have to own traditional enterprises and employees and work for themselves, or say that he is the boss of business and he is the employee, too. Social entrepreneurs refer to those whose goal to start a business is not only to pursue economic benefits, but more importantly to create social values and benefit society. Internal entrepreneurs refer to those who do not necessarily have to run a business, work for a company, take the risk and use innovative methods in the company to turn ideas into final products that can create profits. Policy entrepreneurs refer to those who help government reform public policies and innovative management in order to maximize the value of public services.

The entrepreneurship education in universities aims not only to train talents that can start a business, but also to cultivate more talents with pioneering awareness, risk-taking, entrepreneurial abilities, social and managerial skills, and entrepreneurship and quality, such as social entrepreneurs, internal entrepreneurs, policy entrepreneurs, etc. Meanwhile, the entrepreneurship education in colleges and universities is to explore the creative potential of students, improve their innovative spirit and entrepreneurial ability to promote their employment, entrepreneurship and development.

\section{Introspection and Reconstruction of the Goals of Entrepreneurship Education in Private Colleges and Universities}

The goal of entrepreneurship education, that is the starting point and destination of entrepreneurship education, is the concrete embodiment of the expected result and purpose of entrepreneurship education. If the goal is unclear, entrepreneurship education will not know what to do and where to go.

According to Fan Liu and Jiahua Li, based on the different functions of entrepreneurship education, entrepreneurship education can be classified into three types, entrepreneurship awareness, entrepreneurship general education, and entrepreneurial career. The levels and diversity of entrepreneurship awareness education, entrepreneurship general education and entrepreneurial vocational education, and the specific contents and functions of different types of entrepreneurship education should be seriously considered and must be answered carefully. Entrepreneurship awareness education, as the universal general education, is the primary stage of entrepreneurship education and requires students to correctly understand the role of enterprises in social development and the importance of cultivating basic business skills. Entrepreneurial general education is the middle stage of entrepreneurship education, and requires to develop students' thinking habits of entrepreneurs, and raise students' entrepreneurial spirit, team spirit, professionalism, and improve their employ ability, etc. Entrepreneurial vocational education is the advanced stage of entrepreneurship education, and aims to cultivate students with entrepreneurial potential and help them become future entrepreneurs. ${ }^{[3]}$

With concrete and presentable curriculum objectives and teaching objectives, entrepreneurship education in private universities should establish school-based characteristics of the target system which is based on the reality of private colleges and universities, combines with the students' actual conditions, teacher qualifications, teaching conditions, facilities and equipment, and other comprehensive factors.

Private universities, which are basically applied colleges, cultivate a variety of complex application talents which are oriented to "social needs, employment orientation, moral education first, and ability-based development in an all-round manner" to locate talents, and to cultivate local talents based on the needs of professional posts.

The students of private universities have their own characteristics. Although most of them are slightly poor in their studies, they are well-informed, active in thought, and have extensive interests, a lot of expertise, strong organizational abilities, cooperation, and management skills, etc. In comparison, their employment pressure is much greater than that of students in public universities. Affected by the family or social environment, they have a strong sense of entrepreneurship and a stronger desire to start a business, but these students, who are affected by the education mechanism 
based on the score-based evaluation, although they have entrepreneurial enthusiasm, they lack practical and coping ability, necessary professional knowledge, and confidence when faced with many difficulties in starting a business.

The teaching staff of entrepreneurship education in private universities is so weak that the number of full-time teachers and researchers is seriously insufficient and most existing teachers lack teaching skills and experience in actual business operations, or even have less actual business experience, less opportunities for professional development in the area of entrepreneurship. Although some private universities invite a group of successful entrepreneurs with less teaching experience to hold various entrepreneurial lectures, teaching needs to be greatly improved, as some private colleges and universities lack of organizational coordination, institutional guarantees and financial support, and do not form a long-term mechanism.

Based on the specific conditions of private universities, entrepreneurship education oriented by job entrepreneurship should be carried out in private universities. Its core purpose lies in cultivation and improvement of students' innovation and entrepreneurial quality so that students have the awareness of innovation and entrepreneurship, necessary professional skills and excellent practical ability, and expand their appropriate range of employment. Even if students do not start their own business after graduation, they are able to work in various types of enterprises, government departments, colleges and universities, or if they choose to study for a higher degree, they will also have a stronger sense of innovation and professional competitiveness. Firstly, entrepreneurship education should combine specific professions with the needs of professional positions and integrate innovation. Then, entrepreneurship education as the carrier, should deepen the study of professional knowledge and skills and the cooperation between schools and enterprises, and improve students' practical ability. Finally, entrepreneurs should improve their ability to transfer professional knowledge and use social resources to successfully start a business.

\section{Conclusion}

In general, the training objectives for entrepreneurship education can focus on the following aspects in private universities. First, the training objectives for entrepreneurship education in private universities must combine theory with practice to cultivate students' practical ability and innovation ability to be more competitive and to improve students' employment to become talents so that private colleges and universities should pay more attention to cultivation and training of innovation and professional practice instead of the academic qualification of theoretical knowledge. Second, the training objectives for entrepreneurship education in private universities should be multi-specialized, individualized and diversified, respect students' individual differences and guarantee students' growth so that change the elitist education of "One Thousand People and One Side". Third, an entrepreneurial education system should be built for application-oriented compound talents that meet market demand. To different students in the same major, private universities should adopt different training methods, determine different training directions, and avoid employment difficulties. The cultivation of college students' entrepreneurial awareness is to be strengthened and to be developed throughout the four years of university. In the Employment Guidance class for seniors, teachers should help students recognize the employment situation, specify employment orientation, and provide targeted guidance to students who wish to achieve employment through entrepreneurship and help them achieve entrepreneurship in the future.

\section{Acknowledgement}

The Special Project of Xi'an Social Science Fund: Private College Students Entrepreneurship Education Problems and Countermeasures. (No.15XF01)

Project of Science and Technology Bureau, Chang'an District, Xi'an: A Study on ChuangYi Inclubation Base of Xi'an Fanyi University(No.CC1702) 


\section{References}

[1] Bo Xu, Yuxin He. The Entrepreneurial Rate of Chinese College Students Is Only about 1\% [EB/OL]. http://zqb.cyol.com/html/2014-06/01/nw. D110000zgqnb_20140601_7-01.htm

[2] Hu Yanfang. The analysis of the countermeasures to improve the level of innovation and entrepreneurship of college students in private colleges and universities [J]. Journal of Nanchang College, 2010(1):76-78)

[3] Mingyuan Gu. Colleges and Universities Should Conduct Entrepreneurship Education for Students [J]. Chinese University Teaching, 2002.10:15-16

[4] Fan Liu, Jiahua Li. The Goals and Types of Entrepreneurship Education [J]. China University Student Employment, 2008.2:45-46

[5] Shubiao Liang, Ruilun Zheng. Comparison of the Undergraduates' Entrepreneurship in Private and Public Colleges and Universities in China[J]. Journal of Southwest Agricultural University (Social Science Edition) [J].2013.11:139-141

[6] Minxing Xue, On Thinking about the Orientation of College Students' Entrepreneurship Education in China. Education and Occupation, 2010, (3): 89-91 